УДК 577:113.7:577.3

\title{
MOLECULAR DOCKING STUDY OF OLIGONUCLEOTIDES WITH D-MANNITOL
}

\author{
V. SHCHODRYI, D. LOZHKO, Z. TKACHUK \\ Institute of molecular biology and genetics NASU \\ Ukraine, 03143, Kyiv, 150 Zabolotnogo street \\ e-mail: shodryj1992@gmail.com
}

\begin{abstract}
Aim. Complex of yeast RNA and D-mannitol has a specific antiviral activity. This complex inhibits the neuraminidase and hemagglutinin activity of viruses such as influenza, parainfluenza and thus it blocks virus entry into the cell and his replication. So, nowadays, study of the interaction of this compound is an important task. Study interaction of the oligoribonucleotides and oligodesoxynucleotides with $D$ mannitol molecule. Methods. Molecular modeling structure of oligoribonucleotides and oligodesoxynucleotides were done by using "Hyperchem» software package. The AutoDock program was used to perform accuracy molecular docking. Results. Were obtained binding energies of D-mannitol molecule with oligoribonucleotides and oligodesoxynucleotides. We have shown the possible connections between atoms of oligonucleotides and D-mannitol molecule. Conclusions. The modeling results should give more detailed information about nature of the oligonucleotides binding with a shugar alcohol D-mannitol.
\end{abstract}

Keywords: molecular docking, oligonucleotides, D-mannitol, binding energies.

ntroduction. Therapeutic drugs, which based on ribonucleic acid are actively used in practical medicine. They are highly effective, non-toxic and with a wide range of biological effects [1]. In particular, RNA-containing drugs can increase immune reactivity, have antiviral and anti-inflammatory activity and can regulate main metabolic ways in various pathological conditions [2]. Complex of yeast RNA and D-mannitol has a specific antiviral activity, which is based on a mechanisms of conformation changes of surface antigens and capsid proteins of viruses [3]. This complex inhibits the neuraminidase and hemagglutinin activity of viruses such as influenza, parainfluenza and thus it blocks virus entry into the cell and his replication [4]. D-mannitol is a polymorphic crystalline solid compound, which is widely used in pharmacology as a filler. Also it has ability to structure water membrane, increase the solubility and stability of drugs. Multiple crystal forms of the D-mannitol effect on physical and chemical properties of substances where it is include [5].

RNA and DNA represents one of the most important molecular-cellular targets of several chemotherapeutic drugs. Chemotherapeutic agents targeting DNA can be conveniently categorized, depending on their mode of interaction, into two major classes: (i) covalent binding, and (ii) noncovalent binding, including intercalative binding and DNA majorand minor-groove-binding. Therefore, investigators continue to be interested in designing pharmaceuticals that act at the DNA and RNA level. In this paper, we present application of the flexible ligand docking techniques in order to elucidate the most probable DNA and RNA binding manner with D-mannitol molecule. In future we will do experimental work to prove molecular docking results using different spectroscopic methods [6].

\section{Materials and methods}

The AutoDock 4.0 program was used to perform accuracy molecular docking [7]. Molecular modeling structure of oligoribonucleotides and oligodesoxynucleotides were done by using «Hyperchem» software package [8].

\footnotetext{
(1) V. SHCHODRYI, D. LOZHKO, Z. TKACHUK, 2017 
Procedure of energy minimization of the studied oligonucleotides was produced using force field Amber96 in "Chimera» program package. The AutoDock software package describes the relationship between the ligand and the macromolecule by the translation, orientation, and conformation of the ligand. At the same time, all the torsion angles of the ligand were defined with the AutoTors program so that they could be explored during molecular docking.

Then the 3D grid was created by the AutoGrid algorithm to evaluate the binding energies between the ligand and the DNA. The Lamarckian algorithm in AutoDock 4.0 was applied to search the conformational and orientational space of the Dmannitol.

Docking of oligoribonucleotides with mannitol was additionally performed using the software package HEX 8.0.0 [9], which uses the global docking regime with the simultaneous selection of solutions for complementarity of surfaces and electrostatic interactions and further minimization of molecular energy complexes.

The results obtained using HEX correlate well with the results obtained in AutoDock. The essential disadvantage of the HEX program is that the hard macromolecular docking method is used to model complex structures, as opposed to AutoDock, where flexible docking is used, so in our work, we present the results calculated in the AutoDock program.<smiles>OC[C@H](O)[C@H](O)[C@H](O)[C@H](O)CO</smiles>

Figure 1. Chemical structure of D-mannitol molecule

\section{Results and discussion}

We have studied the interaction of oligoribonucleotides and oligodesoxynucleotides with different nitrogenous bases: adenine, uracil, guanine, thymine and cytosine. For complex formation we used oligoribonucleotides and oligodesoxynucleotides with $1,3,5,10$ and 15 nucleotides. Were obtained complex spatial structure of D-mannitol molecule with oligoribonucleotides and oligodesoxynucleotides. Binding energies were found for each nucleotides and are described for oligoribonucleotides with molecule of D-mannitol in table 1.

Table 1. Binding energies of oligoribonucleotides with molecule of D-mannitol

\begin{tabular}{|c|c|c|c|c|}
\hline \multirow{2}{*}{$\begin{array}{c}\text { Number } \\
\text { of nucleotides }\end{array}$} & \multicolumn{4}{|c|}{$\mathbf{E , ~ k J / m o l}$} \\
\cline { 2 - 5 } & Adenine & Guanine & Cytosine & Uracile \\
\hline 1 & -8.3736 & -7.9549 & -8.3736 & -7.9549 \\
\hline 3 & -15.0724 & -12.1417 & -11.3043 & -12.1417 \\
\hline 5 & -16.3285 & -16.3285 & -14.6538 & -12.2351 \\
\hline 10 & -13.8164 & -16.7472 & -16.7472 & -12.9790 \\
\hline 15 & -14.6538 & -18.0032 & -17.5845 & \\
\hline
\end{tabular}

We have noticed that binding energy of single oligoribonucleotides is different and lies within the range of -7.9549 to $-8.3736 \mathrm{~kJ} / \mathrm{mol}$. For 3 residuelong oligoribonucleotides the binding energy lies in the range of -15.0724 to $-11.30436 \mathrm{~kJ} / \mathrm{mol}$. In this case the binding energy for oligoadenilate with $\mathrm{D}$ mannitol is significantly less in comparison to binding energies for other oligoribonucleotides. For 5 residue-long oligoribonucleotides the binding energy lies in the range of -16.3285 to $-14.2351 \mathrm{~kJ} / \mathrm{mol}$.
For 10 residue-long oligorybonucleotides the binding energy value lies in the range of -16.7472 to $-12.9790 \mathrm{~kJ} / \mathrm{mol}$. The lowest binding energy was observed in case of oligoguanilate. For 15 residuelong oligoribonucleotides the binding energy value was in the range of -18.0032 to $-12.9790 \mathrm{~kJ} / \mathrm{mol}$. The minimum energy pose was observed for oligoriboguanilate with 15 residue - long and is shown in Fig. 2. 


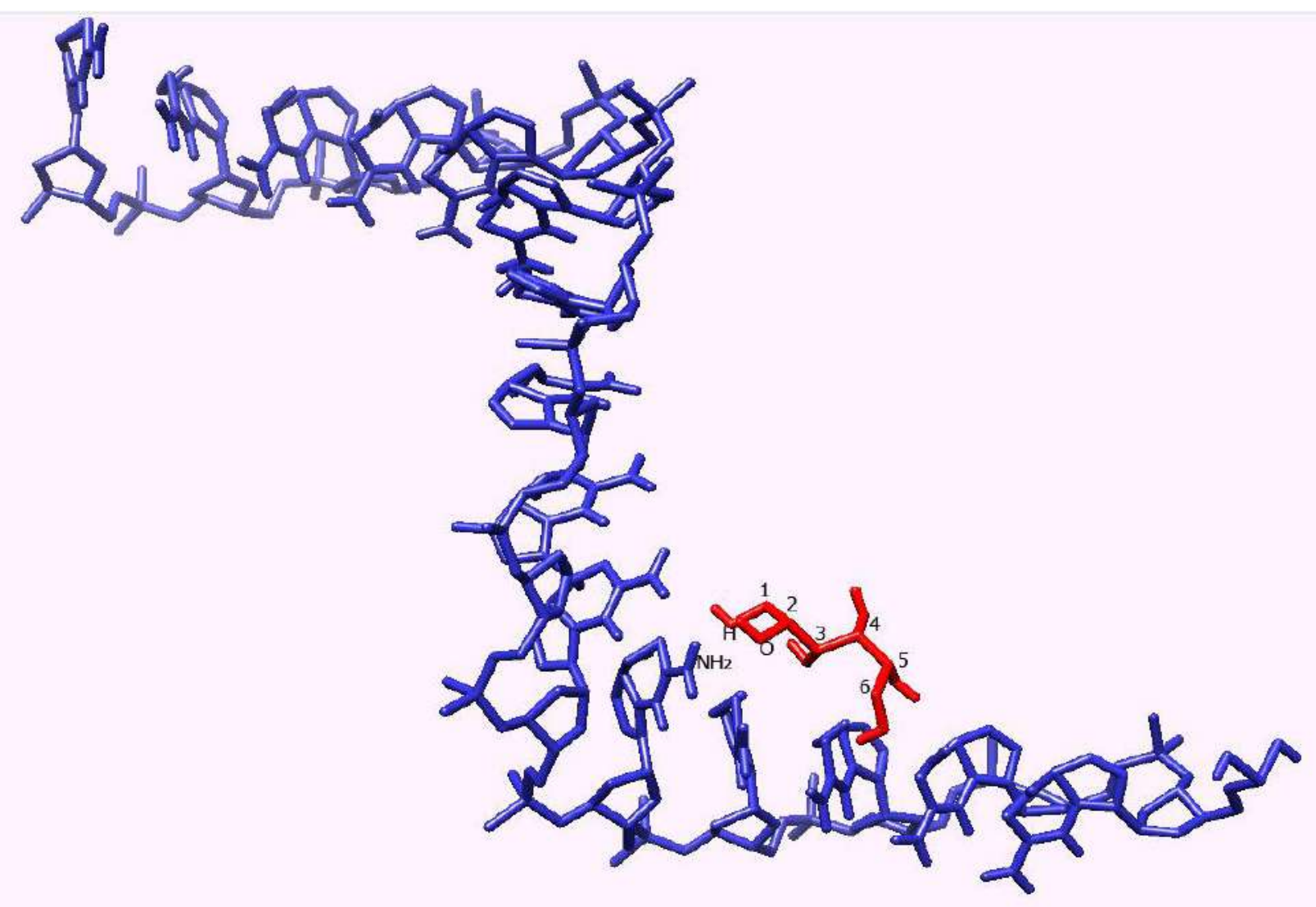

Figure2. Complex formation beetwen oligoriboguanilate (15 residues-long) with D-mannitol molecule (blue = oligoriboguanilate, red = Dmannitol)

Binding energies of oligodesoxynucleotides with molecule of D-mannitol are described in table 2.

We have found that binding energy of single oligodesoxynucleotides is different and lies within the range of -9.6296 to $-7.1175 \mathrm{~kJ} / \mathrm{mol}$. For 3 residue-long oligoribonucleotides the binding energy lies in the range of -13.8164 to $-11.7230 \mathrm{~kJ} / \mathrm{mol}$. In this case the binding energy for oligoadenilate and for oligodesoxyguanilate with D-mannitol are not significantly less in comparison to binding energies for other oligodesoxynucleotides. For 5 residue-long oligodesoxynucleotides the bindig energy lies in the range of -16.7472 to $-12.5604 \mathrm{~kJ} / \mathrm{mol}$. For 10 residue-long oligorybonucleotides the binding energy value lies in the range of -16.3285 to $13.3977 \mathrm{~kJ} / \mathrm{mol}$. The lowest binding energy was observed in case of oligoguanilate. For 15 residuelong oligodesoxynucleotides the binding energy value was in the range of -14.6538 to $-12.9790 \mathrm{~kJ} / \mathrm{mol}$. The lowest energy pose observed for oligodesoxyadenilate with 5 residue - long and is shown in Fig. 3.

Table 2. Binding energies of oligodesoxynucleotides with molecule of D-mannitol

\begin{tabular}{|c|c|c|c|c|}
\hline \multirow{2}{*}{$\begin{array}{c}\text { Number } \\
\text { of nucleotides }\end{array}$} & \multicolumn{4}{|c|}{ E, kJ/mol } \\
\cline { 2 - 5 } & Adenine & Guanine & Cytosine & Thymine \\
\hline 1 & -9.6296 & -7.1175 & -9.2109 & -7.1175 \\
\hline 3 & -13.3977 & -13.8164 & -11.7230 & -12.1417 \\
\hline 5 & -16.7472 & -15.4911 & -12.5604 & -12.5604 \\
\hline 10 & -13.3977 & -16.3285 & -16.3285 & -15.0724 \\
\hline 15 & -14.6538 & -14.2351 & -14.6538 & -12.9790 \\
\hline
\end{tabular}




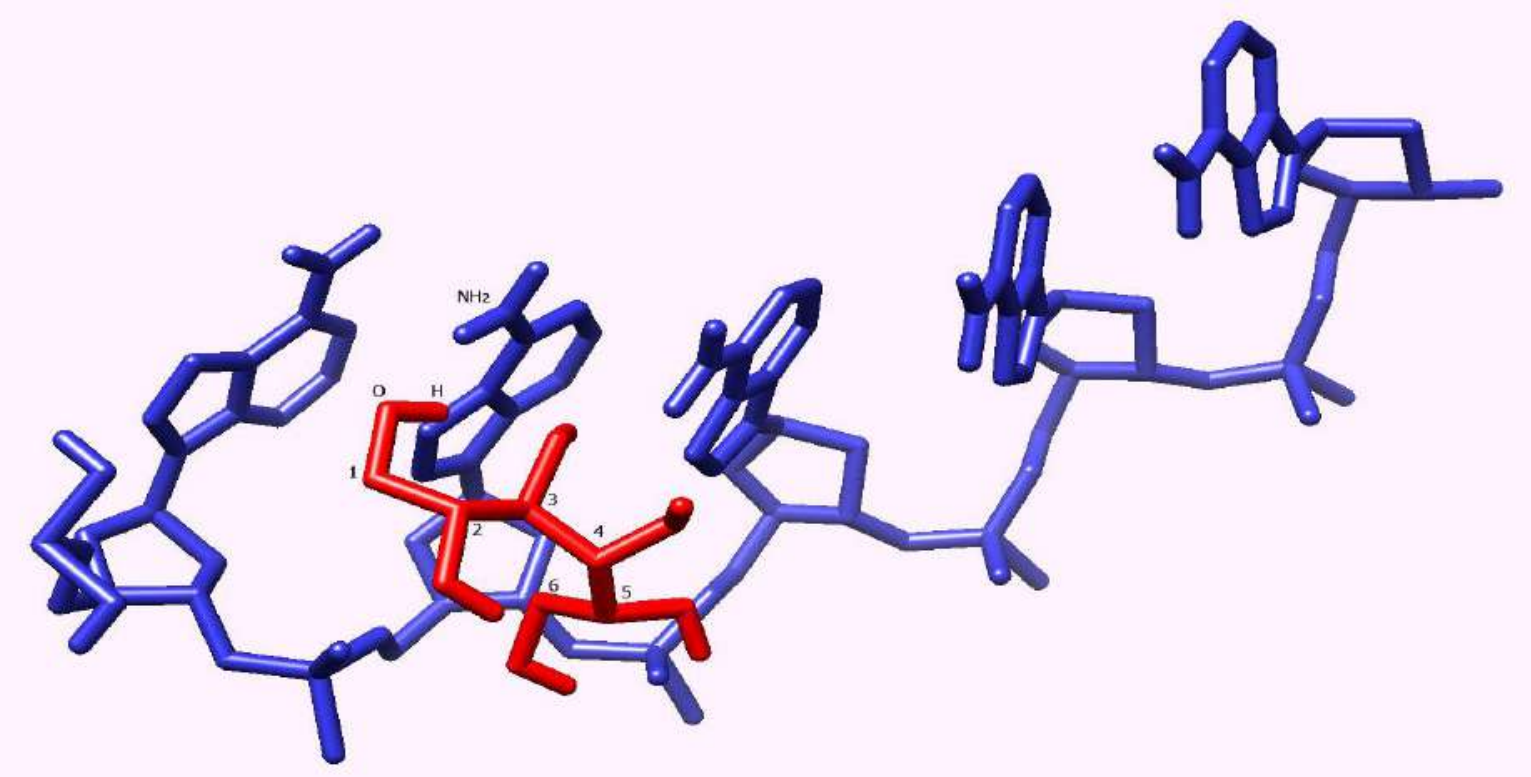

Figure 3. Complex formation beetwen oligodesoxyadenilate (5 residues-long) with $\mathrm{D}$-mannitol molecule (blue = oligodesoxyadenilate, red $=$ D-mannitol)

Also, we have analyzed the distances between oligoribonucleotides and D-mannitol molecule and made decision that atoms and groups, which are the most nearby to each other, will take participation in the interaction.

Table 3. Distances to the most nearby atoms between oligoribonucleotides and mannitol after docking

\begin{tabular}{|c|c|c|c|c|}
\hline \multirow{2}{*}{$\begin{array}{c}\text { Number } \\
\text { of nucleotides }\end{array}$} & \multicolumn{4}{|c|}{ Distances } \\
\cline { 2 - 5 } & Adenosine & Guanosine & Cytosine & Uridine \\
\hline 5 & $1.457 \AA(\mathrm{N})$ & $1.639 \AA\left(\mathrm{NH}_{2}\right)$ & $1.439 \AA\left(\mathrm{NH}_{2}\right)$ & $2.203 \AA(\mathrm{C}=\mathrm{O})$ \\
\hline 10 & $2.246 \mathrm{O}(\mathrm{O})$ & $1.418 \AA\left(\mathrm{NH}_{2}\right)$ & $1.447 \AA \AA\left(\mathrm{NH}_{2}\right)$ & $1.778 \AA(\mathrm{NH})$ \\
\hline 15 & $1.882 \AA(\mathrm{N})$ & $1.838 \AA\left(\mathrm{NH}_{2}\right)$ & $1.884 \AA \AA\left(\mathrm{NH}_{2}\right)$ & $1.876 \AA(\mathrm{C}=\mathrm{O})$ \\
\hline
\end{tabular}

We noticed that D-mannitol molecule will bind to Nitrogen atom within the oligoriboadenilates with the lenght of 5 and 15 residues. Nitrogen atoms are located on the 3 and 5 positions alongside the nitrogenous base accordingly. In case of 10 long oligoriboadenilate D-manitol will bind to Oxygen atom, which is a part of ribosesugar. Oxygen atom is located on 4-th nitrogenous base. In case of oligoriboguanilate with 5,10 and 15 residues, Dmannitol will bind to $\mathrm{NH}_{2}$ groups. $\mathrm{NH}_{2}$ groups are located within the nitrogenous bases accordingly.
Oligoribouracile with 5 and 15 residues will interact with $\mathrm{D}$-mannitol molecule through $\mathrm{C}=\mathrm{O}$ bond within the nitrogenous base. In both cases, $\mathrm{C}=\mathrm{O}$ bonds are located on the 2 position within the nitrogenous bases. Oligoribouracile, which is 10 residues long, will interact with D-mannitol molecule through $\mathrm{N}-\mathrm{H}$ bond within the nitrogenous bases. Oligoribocytosine with 5, 10 and 15 residues long will interact with D-mannitol molecule through $\mathrm{NH}_{2}$ groups which are located within nitrogenous base.

Table 4. Distances to the most nearby atoms between oligoribonucleotides and mannitol after docking

\begin{tabular}{|c|c|c|c|c|}
\hline \multirow{2}{*}{$\begin{array}{c}\text { Number } \\
\text { of nucleotides }\end{array}$} & Adenosine & Guanosine & Cytosine & Uridine \\
\cline { 2 - 5 } & $1.622 \AA\left(\mathrm{NH}_{2}\right)$ & $1.930 \AA(\mathrm{C}=\mathrm{O})$ & $2.185 \AA\left(\mathrm{NH} \mathrm{H}_{2}\right)$ & $1.674 \AA(\mathrm{NH})$ \\
\hline 5 & $2.292 \AA\left(\mathrm{NH}_{2}\right)$ & $1.716 \AA\left(\mathrm{NH}_{2}\right)$ & $1.786 \AA\left(\mathrm{NH}^{2}\right)$ & $1.739 \AA(\mathrm{NH})$ \\
\hline 10 & $2.325 \AA(\mathrm{N})$ & $2.481 \AA\left(\mathrm{NH}_{2}\right)$ & $2.637 \AA\left(\mathrm{NH}_{2}\right)$ & $2.494 \AA(\mathrm{NH})$ \\
\hline 15 & \multicolumn{4}{|l}{}
\end{tabular}


We noticed that D-mannitol molecule will bind to $\mathrm{NH}_{2}$ group within the oligodesoxyadenilates with the lenght of 5 and 10 nucleotides. $\mathrm{NH}_{2}$ group is located alongside the nitrogenous base. In case of 15 long oligodesoxyadenilate D-manitol will bind to Nitrogen atom, which is a part of nitrogenous base. In case of oligodesoxyguanilate with 10 and 15 residues, D-mannitol will bind to $\mathrm{NH}_{2}$ groups. $\mathrm{NH}_{2}$ groups are located within the nitrogenous bases accordingly. In case of 5 long oligodesoxyguanilate $\mathrm{D}$-manitol will bind to $\mathrm{C}=\mathrm{O}$ bond, which is a part of nitrogenous base. Oligodesoxytimin with 5, 10 and 15 residues will interact with D-mannitol molecule through $\mathrm{NH}$ bond within the nitrogenous base. In both cases, $\mathrm{NH}$ bonds are located on the 2 position within the nitrogenous bases. Oligodesoxycytosine with 5 and 15 residues long will interact with $D$ mannitol molecule through $\mathrm{NH}_{2}$ groups which are located within nitrogenous base. In case of 10 long oligodesoxycytosine D-manitol will bind to $\mathrm{NH}$ bond, which is a part of nitrogenous base.

\section{Conclusions}

The primary aim of the present study was to propose a model for the mode of action of $D$ mannitol as a oligonucleotide binding agents. AutoDock was used to model the interaction between oligonucleotides and molecule of $D$ mannitol. The studies enable us to predict more accurately the nature of the interactions between the ligand and oligonucleotides. In this study, we have calculated binding enegries of the studied compounds. Also, we have analyzed the distances between oligoribonucleotides and D-mannitol molecule and made decision that atoms and groups, which are the most nearby to each other, will take participation in the interaction. The study of the interaction of oligonucleotides with the mannitol molecule is the first stage of our study. In this study, we wanted to see to which oligonucleotides the mannitol molecule would be better to interact with. In the future, we plan to investigate this interaction by experimental methods, namely using spectral methods and the method of isothermal titration calorimetry. Compared with traditional/current development approaches, molecular modeling methods should save time and money, especially since the reactivity of newly designed molecules with their targeted DNA and RNA molecules can be predicted prior to chemical synthesis

\section{References}

1. Sullenger B. A., Gilboa E. Emerging clinical applications of RNA. - Nature. - 2002, 418. - P. 252-258.
2. Burnett J. C., Rossi J. J. RNA-Based therapeurics: current progress and future prospects// Chem Biol. - 2012. - V. 19, № 1. - P. 60-71.

3. Tkachuk $Z$. Multiantivirus compound, composition and method for treatment of virus disease. US patent 2014. - May, 13. № 8722642 . - B2. - P. 61

4. Вівчарик М. М., Ільченко О. О., Левченко С. М., Ткачук 3. Ю. Комплексоутворення РНК з манітолом, йогоспектральні характеристики та біологічнаактивність // Доп. АН України. - 2016. — № 10. - Р. 78-83.

5. Ye P., Byron T. Characterization of D-Mannitol by Thermal Analysis. - FTIR, and RamanSpectroscopy. - AMERICAN LABORATORY. - August. - 2008. - P. 24-27.

6. Maurin C., Bailly F., Cotelle P. Structure-Activity Relationships of HIV-1 Integrase Inhibitors - Enzyme-Ligand Interactions // Current Medicinal Chemistry. - 2003. - V 10, № 18. P. 1795-1810.

7. Morris G. M., Huey R., Lindstrom W., Sanner M. F., Belew R. K., Goodsell D. S., Olson A. J. (2009) AutoDock 4 and AutoDockTools4: automated docking with selective receptor flexiblity // J. Computational Chemistry. - 2009. № 16. - P. 2785-2791.

8. HyperChem (TM) Professional 7.51, Hypercube, Inc., 1115 NW 4th Street, Gainesville, Florida 32601, USA.

9. Mustard D., Ritchie D. W. Docking Essential Dynamics Eigenstructures // PROTEINS: Struct. Funct. Bioinf. 2005. - 60, № 2. - P. 269-274.

\section{Представлено О. І. Корнелюком} Надійшла 15.05.2017

\section{ВИВЧЕННЯ ВЗАЄМОДІЇ ОЛІГОНУКЛЕОТИДІВ 3 Д-МАННІТОЛОМ МЕТОДОМ МОЛЕКУЛЯРНОГО ДОКІНГУ}

\section{В. Щодрий, Д. Ложко, З. Ткачук}

Інститут молекулярної біології та генетики НАНУ Україна, 03143, м. Київ, вул. Акад. Заболотного, 150 e-mail: shodryj1992@gmail.com

Мета. Комплекс олігорибонуклеотид з манітолом володіє специфрічною противірусною активністю. Він пригнічує гемаглютинуючу та нейрамінідазну активність вірусів грипу та парагрипу, і таким чином блокує входження вірусів у клітину та його реплікацію. Так, в даний час, дослідження взаємодії цього комплексу $є$ важливим завданням. Дослідження. взаємодії олігорибонуклеотидів та олігодезоксинуклеотидів з молекулою Д-манітолу. Методи. Моделювання молекулярної структури олігорибонуклеотидів і олігодезоксинуклеотидів були зроблені за допомогою програмного пакету «HyperChem». Програма AutoDock була використана для виконання молекулярного докінгу. Результати. Були розраховані енергії зв'язування між молекулою Дманітолу з олігорибонуклеотидами та олігодезоксинуклеотидами. Проведено аналіз відстаней між атомами олігонуклеотидів та молекули Д-маннітолу, котрі найбільш ймовірно вступають у взаємодію. Висновки. Результати молекулярного моделювання повинні дати більш детальну інформацію про природу взаємодії олігонуклеотидів з молекулою Д-манітолу.

Ключові слова: молекулярний докінг, олігонуклеотиди, Д-маннітол, енергія зв'язування. 